Vol. XVII No. 2

\title{
Apparent Courtship Behaviour of Least Flycatcher
}

\author{
by R. W. Nero, Saskatchewan iMuseum of Natural History
}

On May 23, 1958, in the legislative grounds at Regina, Saskatchewan, I observed briefly what appeared to be courtship behaviour of the Least Flycatcher (Empidonax minimus).

At about 10:00 a.m., while searching for migrants in a grove of deciduous trees my attention was drawn to a thin, lispy vocalization being given by a Least Flycatcher which was hopping about in display in the branches of a tree some fifteen feet or so above the ground, and accompanied by a second Least Flycatcher. The displaying bird, which I presumed to be a male, was fluttering its wings, which were held out almost horizontally, and had its tail raised and spread, and its head withdrawn and beak slightly raised. As I watched, the "male" suddenly moved into a crotch formed of several upright branches arising from one place, a suitable nest support typical of sites usually selected by Least Flycatchers. While the "female" moved closer and silently watched from nearby, the "male", still displaying and still emitting a highpitched "song" composed of short, rapid and repetitive notes, hopped about within the crotch, turning in all directions. After a few seconds the two birds moved off and I went on my way; no further observations were made.

This behaviour appeared similar and is, I believe, related to behaviour in the Redwinged Blackbird (Agelaius phoeniceus) that has been termed "symbolic nest-site selection" and "symbolic nest-building" (Nero, 1956). During courtship the redwing male flies slowly down into nesting cover and crawls through the vegetation with wings spread or raised, and on occasion manipulates nesting material, on rare occasions even going into an old nest to so display. The female, newly-arrived or already paired, watches closely from nearby and sometimes follows the male. Related displays have been observed in several members of the blackbird family and other birds. This behaviour may be an attempt by the male to induce the female to begin nesting. It functions, as do most courtship displays, in synchronizing the sexual cycle of male and female. Eventually, the female redwing builds a nest, but only occasionally in the place where the male displayed, hence the use of the term "symbolic".

There is apparently little published description of courtship behaviour in the Least Flycatcher. There is a brief mention of the feeding of the female by the male (Macqueen, 1950 ), and some of the descriptions of the flight song (Macqueen also quotes other authors on this subject) suggest a kind of courtship behaviour. Courtship song-flights and aerial displays are typical of nearly all flycatchers (see Bent, 1942). In describing courtship of the Least Flycatcher, Bent briefly refers to pursuit flights and a gen e r a l ". . . flirting of wings and tail." Courtship behaviour like that described in this note does not appear to have been previously observed in any member of the flycatcher family (Bent, op. cit.; Davis, 1954; Walkinshaw and Henry, 1957). However, the courtship behaviour of these birds is little known; an observer who is able to locate and watch a pair of flycatchers prior to nestbuilding might uncover similar and additional behaviour patterns.

\section{LITERATURE CITED}

BENT, A. C. 1942. Life Histories of North American Flycatchers, Larks, Swallows and their allies. U.S. National Museum Bulletin 179.

DAVIS, D. E. 1954. The breeding biology of Hammond's Flycatcher. Auk, 71:164-171.

MACQUEEN, PEGGY M 1950. Territory and song in the Least Flycatcher. Wilson Bulletin 62:194-205.

NERO, R. W. 1956. A behavior study of the Red-winged Blackbird. Wilson Bulletin, 68:5-37, 129-150.

WALKINSHAW, L. $H$. and C. J. HENRY. 1957. Yellow-bellied Flycatcher nesting in Michigan. Auk, 74:293-304. 